\title{
$\begin{array}{llllllllllllllllllllll}\text { M } & \mathbf{A} & \mathbf{T} & \mathbf{E} & \mathbf{R} & \mathbf{I} & \mathbf{A} & \mathbf{L} & \mathbf{Y} & \text { I } & \mathbf{S} & \mathbf{P} & \mathbf{R} & \mathbf{A} & \mathbf{W} & \mathbf{O} & \mathbf{Z} & \mathbf{D} & \mathbf{A} & \mathbf{N} & \mathbf{I} & \mathbf{A}\end{array}$
}

ROCZNIKI TEOLOGICZNE

$\underline{\text { Tom LXVII, zeszyt } 4 \quad-\quad 2020}$

GRZEGORZ KAMIL SZCZECINA

\section{ROCZNICA POWSTANIA STYCZNIOWEGO. MSZA ŚW. ZA OJCZYZNĘ W WARSZAWSKIM KOŚCIELE ŚW. STANISŁAWA KOSTKI - 30 STYCZNIA 1983 ROKU}

DOI: http://dx.doi.org/10.18290/rt20674-5

\author{
$120^{\mathrm{TH}}$ ANNIVERSARY OF THE JANUARY UPRISING. \\ HOLY MASS FOR THE HOMELAND AT THE WARSAW CHURCH \\ OF SAINT STANISŁAW KOSTKA ON 30 JANUARY 1983
}

\begin{abstract}
The teaching of Blessed Jerzy Popiełuszko falls within the scope of patriotic preaching in Poland. In the years 1982-1984 he celebrated famous church services for the Homeland at the church of Saint Stanislaw Kostka in the Warsaw district of Żoliborz. Each monthly service had a unique form since it included prayers for the Nation, singing, special decoration of the chancel, poetry recitals, and a sermon. All of that was designed to convey a patriotic message, typically focusing on one subject, as each mass was dedicated to a different issue. The liturgy of 30 January 1983 was exceptional, which the martyr for communism celebrated on the $120^{\text {th }}$ anniversary of the January Uprising. In the sermon, he presented the social situation leading to a common effort to regain independence in 1863. Popiełuszko referred to the November Uprising, the Polish-Soviet War and World War II in order to better present the history of Polish efforts to make the Nation and Poland free. The chaplain of the Solidarity Movement used that to strengthen the faithful's love of the Homeland, so that they would become hopeful and steadfast in their struggle for the rights of individual people and society to be respected, disregarded by the totalitarian regime. The whole event was made complete by the use of special decorations and poetic contributions.
\end{abstract}

Key words: Jerzy Popiełuszko; January Uprising; Mass for Homeland; patriotism; history of Poland.

Okres zniewolenia komunistycznego Polski po 1945 roku, a zwłaszcza czas stanu wojennego, był trudnym i bolesnym doświadczeniem w dziejach

Mgr lic. Grzegorz Kamil Szczecina - doktorant Sekcji Historii Kościoła i Patrologii w Instytucie Nauk Teologicznych KUL; adres do korespondencji - e-mail: grzesszczecina@interia.pl; ORCID: https://orcid.org/0000-0001-6866-6165. 
Narodu Polskiego. Jednakże patriotyczne i chrześcijańskie postawy wielu kapłanów były dla ówczesnych rodaków oparciem i wzorem. Wyróżniał się wśród nich bł. ks. Jerzy Popiełuszko, który w latach 1982-1984, w warszawskim kościele p.w. św. Stanisława Kostki na Żoliborzu, sprawował znane w całej Polsce Msze św. za Ojczyznę ${ }^{1}$. W trakcie tych comiesięcznych liturgii w każdą ostatnią niedzielę miesiąca, męczennik komunizmu w głoszonych wówczas kazaniach bronił podstawowych praw człowieka i społeczeństwa $^{2}$. W swoim nauczaniu żoliborski kaznodzieja często nawiązywał do wydarzeń z historii Narodu, a także do ważnych sylwetek w dziejach Polski, by ukazywać chrześcijańskie trwałe wartości, a także remedium dla doświadczonych cierpieniem rodaków w czasie trwającego stanu wojennego ${ }^{3}$. Przykłady z historii Ojczyzny w kaznodziejstwie posłużyły ks. Popiełuszce do wskazania źródła nadziei i świadectwa siły, a przede wszystkim do przykładu odradzania się Narodu nawet w najbardziej tragicznych dziejowych momentach ${ }^{4}$. Dlatego też celem tego artykułu jest przedstawienie tegoż

${ }^{1}$ Alfons (ks. Jerzy) Popiełuszko ur. się 14.09.1947 r. w Okopach niedaleko Suchowoli. Po ukończeniu szkoły średniej w 1965 r. wstąpił do Wyższego Metropolitalnego Seminarium Duchownego w Warszawie. W czasie studiów został na okres dwóch lat powołany do obowiązkowej wówczas służby wojskowej, podczas której pomimo szykan odznaczał się przywiązaniem do Boga i Kościoła. Święcenia kapłańskie przyjął w 1972 r. Od roku 1980 był rezydentem przy parafii św. Stanisława Kostki w Warszawie na Żoliborzu. Organizował pomoc dla rodzin internowanych robotników, których otaczał duszpasterską opieką. Po wielu szykanach i prześladowaniach został uprowadzony i zamordowany przez przedstawicieli Służby Bezpieczeństwa 19.10.1984 r. Beatyfikowany 06.06.2010 r. Proces kanonizacyjny rozpoczął się 20.09.2014 r. w diecezji Crételi we Francji. Zob. E.K. Czaczkowska, T. WiśCiCKI, Ksiądz Jerzy Popietuszko. Wiara, nadzieja, miłość. Biografia błogostawionego, Kraków 2017; E.K. CZACZKowsKA, T. WiśCICKI, Ksiądz Jerzy Popiełuszko, Warszawa 2009; M. KInDzıUK, Jerzy Popiełuszko. Biografia, Kraków 2018; TAż, Świadek prawdy. Życie i śmierć księdza Jerzego Popiełuszki, Częstochowa $2010^{2}$.

${ }^{2}$ Msze św. za Ojczyznę zainicjował ks. T. Bogucki (1908-1987) w 1980 r. Jednak od lutego 1982 r. odprawiano je systematycznie w ostatnią niedzielę miesiąca. Wtedy także ks. Bogucki powierzył ks. Jerzemu Popiełuszce ich celebrowanie, wygłaszanie homilii oraz wszelkie przygotowania organizacyjne. Z. MALACKI, Świadek trudnych czasów, w: Ksiądz Jerzy Popiełuszko. Kazania 1982-1984, red. Z. Malacki, Warszawa 2004, s. 6-7; A. MuLARSKA, Święty wśród nas. Błogosławiony ksiądz Jerzy Popietuszko, Kraków 2015, s. 344-348.

${ }^{3}$ Zob. J. PopieŁuszKo, Homilia z 30 maja 1982 r., w: Kazania 1982-1984 wygłoszone w kościele św. Stanisława Kostki w Warszawie. Bt. ks. Jerzy Popiełuszko, red. G. Bartoszewski, Warszawa 2010, s. 32-34; TenżE, Homilia z 26 września 1982 r., w: Tamże, s. 48-52; TENŻE, Homilia z 31 października 1982 r., w: Tamże, s. 54-58; Tenże, Homilia z 29 maja 1983 r., w: Tamże, s. 100-105; Tenże, Homilia z 30 października 1983 r., w: Tamże, s. 139-146; Tenże, Homilia z 27 listopada 1983 r., w: Tamże, s. 148-153; TenżE, Homilia z 29 stycznia 1984 r., w: Tamże, s. 164-171.

${ }^{4}$ G.K. SzczecinA, Aktualność przestania moralnego bł. ks. Jerzego Popiełuszki w perspektywie przemian społecznych w Polsce po 1984 roku, Nowy Sącz 20182, s. 130. Zob. P. NiTECKI, Znak zwycięstwa. Ksiądz Jerzy Popietuszko (1947-1984), Warszawa 1998, s. 88-139; A. LeweK, Kaznodziejstwo patriotyczne ks. Jerzego Popiełuszki, „Ateneum Kapłańskie” 143(2003), nr 3, s. 476-493. 
przesłania na przykładzie konkretnej patriotycznej liturgii sprawowanej przez Błogosławionego.

Odwołania historyczne zawierały się w patriotycznym przesłaniu Mszy św. za Ojczyznę, które często konkretnym tematem przewodnim i oprawą nawiązywały do ważnych wydarzeń z dziejów Narodu. Dlatego też styczniowa Eucharystia w 1983 roku była upamiętnieniem 120. rocznicy wybuchu powstania z 1863 roku$^{5}$. Należy zaznaczyć, iż dzięki patriotycznej postawie proboszcza ks. Teofila Boguckiego pamięć o styczniowym zrywie niepodległościowym, a zwłaszcza ostatnim jego dyktatorze Romualdzie Traugutcie, była w tej parafii kultywowana i corocznie obchodzona ${ }^{6}$. Jednak szczególny charakter i przesłanie miała ona podczas Mszy św. za Ojczyznę 30 stycznia 1983 roku, którą celebrował ks. Popiełuszko. Warto dodać, iż Błogosławiony już 22 stycznia tegoż roku celebrował liturgię w tzw. kościele dolnym, gdzie z inicjatywy Instytutu Historii UW odprawił Mszę św. w intencji poległych powstańców?

Już we wprowadzeniu do liturgii Mszy św. za Ojczyznę ks. Jerzy, nawiązując do słów abp. Antoniego Fijałkowskiego, który mówił by zawsze bronić spraw Ojczyzny i nie zapominać o tożsamości narodowej, wskazał, iż poprzez pamięć o powstaniu realizuje się cel comiesięcznych modlitw za Polskę. Błogosławiony zwrócił uwagę, że w ten sposób wzmacnia się nadzieja społeczeństwa i troska o dobro państwa: „Wspólną modlitwą za Ojczyznę i tych, którzy dla niej cierpią, wykonujemy jakby testament tego wielkiego arcypasterza Warszawy [...]. Chcemy, aby uroczyste Msze święte za Ojczyznę podtrzymywały w nas ducha umiłowania Ojczyzny, wzmacniały nadzieję, powiększały troskę o dobro wspólnego domu. Aby pomogły nam ze skarbca serc naszych wydobyć to, co najwartościowsze, wszelkie dobro, które pomoże nam zło pokonać"8.

W kazaniu ks. Popiełuszko mówił o znaczeniu walki o wolność i o tym jak ta walka stała się tradycją Polaków9 . Poczynając od powstania listopadowego i styczniowego kapelan „Solidarności” ukazał jak ważne miejsce w historii Ojczyzny zajmują powstania narodowe. Były one nie tylko czynną

${ }^{5}$ Z.E. NiebelSKI, Styczniowe powstanie, w: Encyklopedia Katolicka, t. 18, red. E. Gigilewicz i in., Lublin 2013, kol. 1113-1118.

${ }^{6}$ OŚrodek Dokumentacji Życia i Kultu Ks. Jerzego PopieŁuszki, b. sygn., Kronika parafii p.w. św. Stanistawa Kostki w Warszawie na Żoliborzu 1974-1981; Tamże, b. sygn., Kronika parafii p.w. św. Stanistawa Kostki w Warszawie na Żoliborzu 1982-1985.

${ }^{7}$ E.K. CzaczKowska, T. Wiścicki, Ksiądz Jerzy Popiełuszko. Wiara, nadzieja, miłość, s. 182.

${ }^{8}$ J. PopieŁuszko, Wprowadzenie do Mszy św. za Ojczyznę z 30 stycznia 1983 r., w: Kazania 1982-1984 wygłoszone w kościele św. Stanisława Kostki w Warszawie, s. 67.

9 P. MilcareK, Jerzy Popiełuszko. Kapłan Miłości, Warszawa 2014, s. 129. 
walką o upragnioną wolność i niepodległość, ale także przykładem i przejawem patriotyzmu rodaków ${ }^{10}$. W nich ks. Popiełuszko widział analogię do czasów sobie współczesnych, do zniewolenia komunistycznego, dlatego też na początku kazania 30 stycznia 1983 roku, przywołując koleje losu dążeń niepodległościowych rodaków powiedział: „Umieli Polacy bronić Ojczyzny przed najeźdźcą, umieli upominać się o prawdziwą i pełną wolność dla niej w czasie zaborów. Towarzyszyły im zawsze światła Ewangelii Chrystusa, że wolność jest darem Boga samego. Wiele było powstań i zrywów narodowych, z których na szczególną uwagę zasługują powstanie listopadowe i styczniowe, bo oba tak wciąż są nam bliskie i tak wiele jest w nich analogii do naszej rzeczywistości"11.

Patriotyczna liturgia wraz z nauczaniem ks. Jerzego była nie tylko modlitwą za Polskę, ale również lekcją historii, którą męczennik zawarł w kazaniu. Przypomniał w nim czasy zaborów oraz okoliczności społeczne powstania styczniowego, tłumne manifestacje patriotyczne i wiążące się z nimi zaborcze represje: „Rok 1863. Spróbujmy wczuć się w sytuację, nastroje i niektóre przyczyny, które doprowadziły naszych praojców do poderwania się do tej jakże nierównej walki w zimowy wieczór 22 stycznia 1863 roku. Kiedy po 25 latach trwania stanu wojennego, wprowadzonego w czasie powstania listopadowego, zostaje on zniesiony w 1856 roku, zło wprawdzie się zmniejszyło, ale wzmogła się wrażliwość ludzi [...]. Ludzie, jak nigdy, zaczynają się licznie gromadzić w kościołach, uroczyście obchodzą rocznice, o których przedtem kazano milczeć. Gdy w trzydziestą rocznicę powstania listopadowego po Mszy świętej w kościele Karmelitów zachęcano, by ludzie zebrali się tego wieczoru jeszcze raz, spontanicznie przybyły tysiące mieszkańców Warszawy. Na dany znak, pomimo błota wszyscy padli na kolana na bruk i ze łzami w oczach odśpiewali «Boże, coś Polskę». Wzbierały coraz bardziej uczucia patriotyczne, ludzie mocno wzięli sobie do serca wołanie «Ojczyznę, wolność, racz nam wrócić, Panie». Od tej pory uczucia patriotyczne były demonstrowane przy różnych okazjach [...]. Dla władzy, która przyzwyczajona, że społeczeństwo pracuje i milczy, ta lawina manifestowania patriotyzmu była całkowitym zaskoczeniem. Postanowiła zareagować użyciem siły. 27 lutego 1861 roku po wyjściu z kościoła na Lesznie padło 55 strzałów. Zginęło pięciu mężczyzn, a kilkanaście osób zostało rannych"12.

\footnotetext{
${ }^{10}$ G.K. SzczecinA, Aktualność przestania moralnego bt. ks. Jerzego Popiełuszki, s. 129-130.

${ }^{11}$ J. PopieŁuszKo, Homilia z 30 stycznia 1983 r., w: Kazania 1982-1984 wygłoszone w kościele św. Stanisława Kostki w Warszawie, s. 68.

12 Tamże, s. 69-70.
} 
Ks. Jerzy, umacniając w rodakach nadzieję i patriotyczne wartości, wskazywał na historyczne wydrzenia oraz determinację Polaków jako wzór w okazywaniu miłości do Ojczyzny oraz kultywowaniu tradycji. Dlatego w kazaniu w czasie omawianej Mszy św. z 1983 roku jako przykład przywołał demonstracje patriotyczne związane z pogrzebem abp. Antoniego Fijałkowskiego, czy w rocznicę śmierci Tadeusza Kościuszki. Błogosławiony w perspektywie historycznej ukazywał wolność Narodu, który pomimo zniewoleń nigdy nie utracił tożsamości. Kapelan warszawskich hutników w kazaniu przypominał, że Polacy kosztem krwi bronili Polski i symbolów państwa, zawsze walczyli przeciw przemocy i dążyli do wolności oraz niepodległości ${ }^{13}$.

Mówiąc o samym powstaniu styczniowym żoliborski męczennik zwrócił uwagę słuchaczy, iż: „lud w zimowy wieczór 22 stycznia 1863 roku poderwał się do powstania zbrojnego. Powstania, które choć przegrane, poszerzyło niepomiernie krąg Polaków świadomych swej tożsamości, świadomych spuścizny ojców i dziadów, świadomych swych dążeń jako naród. Było ono wielkim ziarnem rzuconym w polską glebę. I nadal pozostała w świadomości dążność do wolności, w myśl tego co mówił poeta «walka o wolność, gdy się zaczyna, z ojca krwią spada dziedzictwem na syna...»"14.

Lekcja historii Polski, zawarta w kazaniu ks. Popiełuszki z Mszy św. za Ojczyznę z 30 stycznia 1983 roku, została uzupełniona przez niego o kontekst odzyskania niepodległości w 1918 roku, wojnę polsko-bolszewicką, II wojnę światową i powstanie warszawskie ${ }^{15}$. Wszystkie te wydarzenia według kaznodziei - były kontynuacją i spuścizną pokoleń rodaków w zmaganiu się dziejowym o wolność Ojczyzny ${ }^{16}$. Tym samym w historyczno-narodowy przekaz nauczania Błogosławionego została włączona katecheza o wolności, która charakteryzowała przepowiadanie kapelana „Solidarności” ${ }^{17}$. Ks. Jerzy powiedział: „Wolność jest rzeczywistością, którą Bóg wszczepił w człowieka, stwarzając go na swój obraz i podobieństwo. Naród z tysiącletnią tradycją chrześcijańską zawsze będzie dążył do pełnej wolności.

\footnotetext{
${ }^{13}$ E.K. CZaczkowska, T. WiŚCiCKI, Ksiądz Jerzy Popietuszko. Wiara, nadzieja, miłość, s. 183.

${ }^{14}$ J. PopieŁuszko, Homilia z 30 stycznia 1983 r., s. 72. Cyt. za: A. Mickiewicz, Giaur, w: Poematy, dzieła, t. II, oprac. Cz. Zgorzelski, Warszawa 1997, s. 163.

${ }^{15}$ Tamże, s. 72-73.

${ }^{16}$ G.K. Szczecina, Aspekty historyczne w przepowiadaniu bt. ks. Jerzego Popieluszki, „Roczniki Teologiczne" 64(2017), z. 4, s. 164.

${ }^{17}$ Zob. R. SoBczAK, Ksiadz Jerzy Popiełuszko obrońca praw człowieka, w: Nauczanie spoteczne i męczeństwo ks. Jerzego Popiełuszki, red. T. Guz, A. Niedużak, R. Tłuczek, Lublin, 2009, s. 125-132; M. SZCZĘSNY, Aktualność społecznego nauczania ks. Jerzego Popiełuszki, w: Tamże, s. 133-153; G.K. Szczecina, Godność i wolność człowieka w nauczaniu bt. ks. Jerzego Popietuszki, „Studia Pelplińskie” 47(2015), s. 225-238.
} 
Bo dążenia do wolności nie pokona się przemocą, gdyż przemoc jest siłą tego, kto nie posiadł prawdy. Człowieka można przemocą ugiąć, ale nie można go zniewolić. Polak miłujący Boga i Ojczyznę powstanie z każdego poniżenia, bo zwykł klękać tylko przed Bogiem. Zbyt wiele mamy tego przykładów w historii zamierzchłej, jak i współczesnej"18.

W tym też przesłaniu i historycznym dziedzictwie powstania styczniowego ks. Jerzy zawarł ówczesne dążenia rodaków do życia w wolności, poszanowania praw człowieka oraz społeczeństwa. Jak zauważył, aspiracje niepodległościowe nie zakończyły się po II wojnie światowej, gdyż czasy powojenne i strajki robotników były kolejnymi zrywami o przestrzeganie godności człowieka oraz przejawem wolnościowych ambicji Polaków. Na dowód tego przytoczył słowa kard. Stefana Wyszyńskiego, który wskazał, iż udręczenie Narodu, zmuszanie ludzi do milczenia, ograniczenia wolności myślenia, światopoglądu czy wydajnej pracy, co było efektem rządów komunistycznych w Polsce, stało się powodem zrywu wolności zawartym w solidarnościowym ruchu lat osiemdziesiątych XX wieku ${ }^{19}$.

Kończąc kazanie ks. Popiełuszko przypomniał słowa ówczesnego prymasa kard. Józefa Glempa o prawie ludzi do protestów i domagania się swoich praw. Błogosławiony powiedział: „Módlmy się dzisiaj, w 120. rocznicę patriotycznego zrywu powstańców, o to, abyśmy umieli pielęgnować dążność do prawdziwej wolności w nas samych, w naszych rodzinach, w środowiskach i miejscach pracy oraz całym naszym narodzie"20.

Dopełnieniem patriotycznego przekazu Mszy św. za Ojczyznę, w 120. rocznicę powstania styczniowego, była dekoracja plastyczna w prezbiterium świątyni. Na specjalnej dużej planszy artyści umieścili białego orła (godło Polski niepodległej $\mathrm{z}$ okresu międzywojennego) w złotej koronie, na czerwonym tle. Było to bezpośrednim nawiązaniem do II Rzeczypospolitej, utożsamianej $\mathrm{z}$ realną wolnością. To odwołanie było charakterystycznym elementem comiesięcznych nabożeństw w kościele p.w. św. Stanisława Kostki. U dołu planszy z orłem, w lewej części, umieszczono datę 1863, a po prawej stronie rok 1983 - jako nawiązanie do rocznicy powstania. Pod datami zamieszczono wymowny napis: „Powstań Polsko”, który wzywał do rewolucji moralnej, co miało odbicie w kaznodziejstwie żoliborskiego kapłana. Nawiązaniem do zrywu niepodległościowego z XIX wieku, jako walki

\footnotetext{
18 J. PopieŁuszKo, Homilia z 30 stycznia 1983 r., s. 74.

19 Tamże, s. 73.

20 Tamże, s. 75.
} 
o wolność Polski, było umieszczenie pod dekoracją figur dwóch powstańców stolicy - dzieci, z sierpnia 1944 roku $^{21}$.

Przekaz rocznicowy liturgii wybrzmiał dobitnie w modlitwie wiernych czytanej przez przedstawicieli ludzi pracy. Poza stałymi intencjami w szczególny sposób modlono się za poległych w obronie Ojczyzny na przestrzeni wieków, w tym: „za tych, którzy oddali krew Ojczyźnie w walce z zaborcą w czasie powstania styczniowego, aby ich poświęcenie Bóg nagrodził szczęściem wiecznym" 22 . Z ofiarą powstańców zostało również w tym elemencie Eucharystii zestawione ówczesne cierpienie rodaków oraz ich dążenia do poszanowania podstawowych praw, co wyrażało dziejową spuściznę zmagań Polaków o wolność ${ }^{23}$. To nawiązanie historyczne zostało wyrażone również w pieśniach religijno-patriotycznych śpiewanych w czasie liturgii, które zostały przywołane również przez ks. Jerzego w kazaniu, a szczególnie wyrażały wartości narodowe oraz duchową niepodległość rodaków. Podobnie jak w czasach zaborów, powstania styczniowego i tym razem śpiewano je, w klimacie zbliżonym do doświadczenia Narodu w połowie XIX wieku. W czasie Mszy św. za Ojczyznę wierni, unosząc przyniesione krzyże, śpiewali m.in. „Boże, coś Polskę”, „My chcemy Boga” oraz „Nie rzucim, Chryste, świątyń Twych" 24 .

Oprawa poetycka Mszy św. za Ojczyznę w styczniu 1983 roku korelowała z dziejami Narodu i nawiązaniami historycznymi kazania. Artyści recytowali wiersze m.in.: Zygmunta Krasińskiego, Ernesta Brylla czy Wisławy Szymborskiej25. Poezja przypominała obecnym długie dzieje społecznych cierpień, jak również niezachwianą postawę przodków w sprawie walki o wolność Ojczyzny. Ukazywała źródło siły i nadziei przodków, którą czerpali z wiary ${ }^{26}$. W kontekście rocznicowym i nawiązań historycznych w kazaniu oraz oprawie plastycznej Mszy św., dobitnie i przejmująco brzmiał wiersz Teresy Boguszewskiej, który recytowała jedna z aktorek: „Moja Polska poszarzała,/Jak kobiety twarz zmęczonej,/Bez uśmiechu, bez nadziei/ W posmutniałych troską oczach./Moja Polska zagubiona/Stoi na rozstajnych

\footnotetext{
${ }^{21}$ G.K. Szczecina, Religijno-patriotyczne przesłanie wybranych dekoracji plastycznych z żoliborskich „Mszy św. za Ojczyznę” (1982-1984), „Roczniki Teologiczne” 65(2018), z. 4, s. 105.

${ }^{22}$ Modlitwa wiernych z Mszy św. za Ojczyznę 30 stycznia 1983 r., w: Ks. Jerzy Popiełuszko. Ofiara spetniona. Msze święte za Ojczyznę odprawiane w kościele św. Stanisława Kostki w Warszawie w latach 1982-1984, red. G. Bartoszewski, Warszawa 2004, s. 133.

23 Tamże.

${ }^{24}$ Msza św. za Ojczyznę 30 stycznia 1983 r., w: Ks. Jerzy Popietuszko. Ofiara spetniona, s. $122-134$.

${ }^{25}$ Poezje i recytacje. Styczeń 1983, w: Tamże, s. 454-460.

${ }^{26}$ G. SiKORSKA, Prawda warta życia. Ks. Jerzy Popietuszko, Londyn 1985, s. 41.
} 
drogach,/Z krzyżem cierpień na ramionach/Tak bolesnych jak Golgota [...]/ Moja Polska zapłakana/Łzami matek nad grobami,/Patrzy czernią otulona /Droga ściele się krzyżami./Moja Polska zatroskana/Losem dzieci swych najlepszych,/Uwięzionych i wygnanych,/Rozrzuconych gdzieś po świecie./ Moja Polska rozmodlona,/By polskości nie zagubić,/Wraz z Maryją w jej kościołach/Udręczony naród tuli”27.

Poprzez historyczne odwołania w kazaniach, celebrowanie rocznic, m.in. powstania styczniowego, bł. ks. Jerzy Popiełuszko nie tylko wpisywał się w nurt polskiego kaznodziejstwa patriotycznego, ale przede wszystkim ukazywał, że pamięć dziejowa jest ważnym elementem rozumienia teraźniejszości i polskości. Wskazywał, że o wolność Ojczyzny i poszanowanie praw społeczeństwa należy zawsze zabiegać i troszczyć się. Było to odważne i wymowne w czasie terroru stanu wojennego oraz deptania godności ludzkiej. Dlatego też przepowiadanie ks. Popiełuszki budziło z jednej strony duży entuzjazm wiernych, z drugiej zaś wyraźne zaniepokojenie struktur partyjnych PRL-u ${ }^{28}$. Ukazanie zrywu niepodległościowego z 1863 roku i dążeń Polaków do wolności było nie tylko lekcją pamięci, ale formacją patriotycznych postaw rodaków i mobilizacją w nadziei na wyzwolenie Ojczyzny oraz zapałem w dążeniach wolnościowych rodaków, a przede wszystkim podtrzymaniem nadziei $\mathrm{w}$ tak trudnym momencie dziejów. Błogosławiony, podnosząc na duchu wiernych, uświadamiał o obowiązku miłości do Polski, nawiązując do historii Narodu, wskazywał bolesne i szczytne momenty dziejów Polski, by ożywiać u słuchaczy ową miłość ${ }^{29}$. Egzemplifikacją tego jest świadectwo robotników przysłane do żoliborskiej parafii po Mszy św. za Ojczyznę 30 stycznia 1983 roku: „Przyjechaliśmy z Kołobrzegu, aby wspólnie przeżyć podniosłe chwile. Przedstawiciele społeczeństwa katolickiego z Kołobrzegu kilkakrotnie uczestniczyli w nabożeństwach i zawsze wracali z nieopisaną wdzięcznością, że dane im było wysłuchać i przeżyć tak wspaniałą lekcję patriotyzmu i wiary w naszego Stwórcę [...]. Serca nasze spragnione są nadziei, aby móc przetrwać razem te ciężkie miesiące i lata w naszej Ojczyźnie. Wierzymy, że Bóg jest naszą ostoją i nieustanne pragnienie wolności tkwiące $\mathrm{w}$ narodzie polskim i osobno w każdym z nas doprowadzi do zwycięstwa, jak Chrystus zwyciężył śmierć na krzyżu. Ponieważ bezpośrednio po Mszy świętej udajemy się na dworzec, aby wrócić do naszych domów, i zabraknie nam czasu na osobiste wyrażenie naszych podziękowań -

\footnotetext{
${ }^{27}$ T. Boguszewska, Moja Polska, w: Ks. Jerzy Popietuszko. Ofiara spetniona, s. 454-455.

${ }^{28}$ A. LEWEK, Kaznodziejstwo patriotyczne ks. Jerzego Popiełuszki, s. 481-482.

${ }^{29}$ G.K. SzCZECINA, Aspekty historyczne w przepowiadaniu bt. ks. Jerzego Popiełuszki, s. 171-172.
} 
czynimy to w tej chwili. Zapewniamy, że przekażemy to wszystko, co przeżyliśmy i zobaczyliśmy $\mathrm{w}$ Warszawie, wszystkim tym, którzy pragnęliby również wziąć udział - a nie mają możliwości”30.

\section{BIBLIOGRAFIA}

ŹRÓDŁA

Boguszewska T., Moja Polska, w: Ks. Jerzy Popietuszko. Ofiara spetniona. Msze święte za Ojczyznę odprawiane w kościele św. Stanisława Kostki w Warszawie w latach 1982-1984, red. G. Bartoszewski, Warszawa 2010, s. 454-455.

Kazania 1982-1984 wygłoszone w kościele św. Stanisława Kostki w Warszawie. Bt. ks. Jerzy Popietuszko, red. G. Bartoszewski, Warszawa 2010.

Modlitwa wiernych z Mszy św. za Ojczyzne 30 stycznia 1983 r., w: Ks. Jerzy Popieluszko. Ofiara spetniona. Msze święte za Ojczyznę odprawiane w kościele św. Stanistawa Kostki w Warszawie w latach 1982-1984, s. 132-134.

Msza św. za Ojczyznę 30 stycznia 1983 r., w: Ks. Jerzy Popietuszko. Ofiara spetniona. Msze święte za Ojczyznę odprawiane w kościele św. Stanistawa Kostki w Warszawie w latach 19821984, s. 122-134.

OŚrodek Dokumentacji Życia i Kultu Ks. JerZego PopięuszKi, b. sygn., Kronika parafii p.w. św. Stanisława Kostki w Warszawie na Żoliborzu 1974-1981.

OŚrodek Dokumentacji Życia i Kultu Ks. Jerzego PopieŁuszKi, b. sygn., Kronika parafii p.w. św. Stanistawa Kostki w Warszawie na Żoliborzu 1982-1985.

\section{LITERATURA}

Czaczkowska E.K., Wiścicki T., Ksiądz Jerzy Popietuszko, Warszawa 2009.

Czaczkowska E.K., Wiścicki T., Ksiądz Jerzy Popietuszko. Wiara, nadzieja, miłość. Biografia błogosławionego, Kraków 2017.

KInDZIUK M., Jerzy Popietuszko. Biografia, Kraków 2018.

KindzıuK M., Świadek prawdy. Życie i śmierć księdza Jerzego Popiełuszki, Częstochowa $2010^{2}$.

LeweK A., Kaznodziejstwo patriotyczne ks. Jerzego Popiełuszki, „Ateneum Kapłańskie” 143 (2003), nr 3, s. 476-493.

Malacki Z., Świadek trudnych czasów, w: Ksiądz Jerzy Popiełuszko. Kazania 1982-1984, red. Z. Malacki, Warszawa 2004, s. 3-8.

Mickiewicz A., Giaur, w: Poematy, dzieła, t. II, oprac. Cz. Zgorzelski, Warszawa 1997, s. 163.

MilcareK P., Jerzy Popiełuszko. Kapłan Mitości, Warszawa 2014.

Mularska A., Święty wśród nas. Błogosławiony ksiadz Jerzy Popiełuszko, Kraków 2015.

NiEBELSKi Z.E., Styczniowe powstanie, w: Encyklopedia Katolicka, t. 18, red. E. Gigilewicz i in., Lublin 2013, kol. 1113-1118.

\footnotetext{
${ }^{30}$ P. MilcareK, Jerzy Popiełuszko. Kapłan Miłości, s. 130.
} 
Nitecki P., Znak zwycięstwa. Ksiadz Jerzy Popietuszko (1947-1984), Warszawa 1998.

Poezje i recytacje. Styczeń 1983, w: Ks. Jerzy Popietuszko. Ofiara spetniona. Msze święte za Ojczyznę odprawiane w kościele św. Stanisława Kostki w Warszawie w latach 1982-1984, red. G. Bartoszewski, Warszawa 2004, s. 454-460.

SiKorska G., Prawda warta życia. Ks. Jerzy Popietuszko, Londyn 1985.

SobczaK R., Ksiądz Jerzy Popiełuszko obrońca praw człowieka, w: Nauczanie społeczne i męczeństwo ks. Jerzego Popiełuszki, red. T. Guz, A. Niedużak, R. Tłuczek, Lublin 2009, s. 125-132.

Szczecina G.K., Aktualność przestania moralnego bt. ks. Jerzego Popietuszki w perspektywie przemian społecznych w Polsce po 1984 roku, Nowy Sącz $2018^{2}$.

Szczecina G.K., Aspekty historyczne w przepowiadaniu bt. ks. Jerzego Popietuszki, „Roczniki Teologiczne" 64(2017), z. 4, s. 157-174.

Szczecina G.K., Godność i wolność człowieka w nauczaniu bł. ks. Jerzego Popiełuszki, „Studia Pelplińskie" 47(2015), s. 225-238.

SzCZECINA G.K., Religijno-patriotyczne przestanie wybranych dekoracji plastycznych z żoliborskich „Mszy św. za Ojczyznę” (1982-1984), „Roczniki Teologiczne” 65(2018), z. 4, s. 97-110.

SzCZĘSNY M., Aktualność społecznego nauczania ks. Jerzego Popiełuszki, w: Nauczanie społeczne i męczeństwo ks. Jerzego Popiełuszki, s. 133-153.

\section{ROCZNICA POWSTANIA STYCZNIOWEGO. \\ MSZA ŚW. ZA OJCZYZNĘ W WARSZAWSKIM KOŚCIELE ŚW. STANISŁAWA KOSTKI- 30 STYCZNIA 1983 ROKU}

\section{STRESZCZENIE}

Nauczanie bł. ks. Jerzego Popiełuszki wpisuje się w nurt kaznodziejstwa patriotycznego w Polsce. W latach 1982-1984 sprawował on słynne w kraju Msze św. za Ojczyznę w kościele p.w. św. Stanisława Kostki na warszawskim Żoliborzu. Wyjątkowa była oprawa każdego z comiesięcznych nabożeństw, na które składała się modlitwa za Naród, śpiew, dekoracja plastyczna $\mathrm{w}$ prezbiterium, recytacja poezji oraz kazanie. Wszystko to było utrzymane w patriotycznym przekazie, a przede wszystkim w danym temacie, gdyż każda z Mszy św. za Ojczyznę była poświęcona innemu zagadnieniu. Wyjątkową była liturgia z 30 stycznia 1983 roku, którą męczennik komunizmu sprawował $\mathrm{w} 120$. rocznicę powstania styczniowego. W kazaniu przedstawił on sytuację społeczną poprzedzającą zryw niepodległościowy w 1863 roku. Przywołał powstanie listopadowe, wojnę polsko-bolszewicką oraz II wojną światową dla lepszego zobrazowania dziejowego zmagania się rodaków o wolność Narodu i Polski. Posłużyło to kapelanowi „Solidarności” do utwierdzenia wiernych w miłości do Ojczyzny, a także w nadziei oraz wytrwałości w zmaganiu się o poszanowanie praw człowieka i społeczeństwa, nierespektowanych przez totalitarny reżim. Dopełnieniem treści była m.in. dekoracja oraz przesłanie poetyckie oprawy artystycznej.

Słowa kluczowe: Jerzy Popiełuszko; powstanie styczniowe; Msza św. za Ojczyznę; patriotyzm; historia Polski. 